\title{
Protected Birds of Nepal: A Review of their Status, Distribution and Habitat
}

Hem S. Baral ${ }^{1}$

\begin{abstract}
National Parks and Wildlife Conservation Act, 1973 is the major Act that forms the basis for biodiversity protection in Nepal. The Act lists nine species of birds protected by law. These species are Tragopan satyra (Satyr Tragopan), Lophophorus impejanus (Danphe), Catreus wallichi (Cheer), Buceros bicornis (Great Hornbill), Houbaropsis bengalensis (Bengal Florican), Sypheotides indica (Lesser Florican), Grus antigone (Sarus Crane), Ciconia ciconia (White Stork) and C. nigra (Black Stork). As these birds were listed on the Act several years back, there is a need to update the list taking into account the available information on Nepal's birds. Himalayan Nature funded by Critical Ecosystem Partnership Fund and World Wildlife Fund (WWF Nepal) is working to recommend updated list to Nepal government.

राष्ट्रिय निकुज्ज तथा वन्यजन्तु संरक्षण ऐन, २०२९, नेपालको जैविक विविधता संरक्षण गर्ने प्रमुख ऐन हो। यस ऐनले सरकारलाई नयाँ संरक्षित क्षेत्रहरूको स्थापना र विस्तार गर्ने अधिकार प्रदान गरेको छ। यस ऐन अन्तर्गत पंछीका नौ प्रजातिहरूलाई संरक्षित जनावरको सूचीमा राखिएको छ। यी पंछीहरू यस प्रकार छन्: मुनाल, डाँफे, चीर, राजधनेश, खरमुजुर, सानो खरमुजुर, सारस, सेतो गरूड र कालो गरूड। यो ऐन सुरुमा बनेदेखि केही संशोधन भएतापनि पंछीहरूको सूचीमा केही हेरफेर भएको छैन। संशोधनको लागि हिमाली प्रकृति, अन्य सहयोगी संस्था र विज्ञको सल्लाह अनुसार नेपाल सरकारलाई प्रतिवेदन पेश गर्ने तरखरमा छ।
\end{abstract}

Key Words: National Park and Wildlife Conservation Act, Protected birds of Nepal, Status update

\section{Introduction}

A national conservation programme was initiated by Nepal government in 1971 (MoFSC 2002). This was given a legal basis following the passing of the National Parks and Wildlife Conservation Act 2029 in March 1973, which provided basis for the establishment and administration of protected areas and 'the conservation of animals and birds and their habitats' (MoFSC 2002). The 1973 Act enables Nepal government to establish any area as a national park, wildlife reserve, conservation area or hunting reserve. This Act is the main framework under whose guidance policy and action of Department of National Parks and Wildlife Conservation are made and implemented. This Act prohibits hunting of any animals or birds, building any house, hut or other structure, clearing or cultivation in any part of the land or harvesting any crops, cutting, burning or damaging any tree, bush or other forest product, and mining within national parks or protected areas in the Terai. The Act has been amended

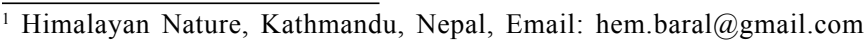


four times (1974, 1982, 1989 and 1991), but no efforts have been made to make a thorough amendment of the Act for over a decade. The Act defines wildlife as any wild animals including mammals, birds, fish and reptiles. Although far from perfect, this Act has been a key instrument in protecting biodiversity within the protected areas (PAs) system.

According to this Act, nine bird species found in Nepal are protected (Baral and Inskipp 2004). The Act needs revision to incorporate not only different species of birds that need protection but also to incorporate various developments in the field of ornithology research and conservation. Currently, Critical Ecosystem Partnership Fund-WWF Nepal funded project is ongoing to revise the existing list of protected animals under the aegis of Himalayan Nature (http://himalayannature.org/index/index.php?page=activities). So far it has been a tedious work to find consolidated information on all the nine species at one place. This paper attempts to provide an update on the status, distribution and into the ecology of the nine protected birds in Nepal.

\section{Munal or Satyr Tragopan (Tragopan satyra)}

World distribution: Himalayas of Nepal, India, Bhutan and China

World population: No estimate available

Nepal population: 1000-3000 (Estimate)

IUCN/BirdLife International: Near-threatened

CITES: Appendix III.

\section{Field characters}

Length: $50.5-63 \mathrm{~cm}$, Weight: $1-2.1 \mathrm{~kg}$. This is one of the most spectacularly coloured pheasant of Nepal. Often the bird is referred as jewels of the forest and is one of the most sought after birds by ornithologists world over. The male is predominantly red in colour and the female is brown. Head, recumbent crest, and a loop round the deep blue semi-naked throat patch are black in a male bird. A crimson streak on either side of crest is present. General plumage above and below is rich orange crimson, olive-brown on back and rump, sprinkled all over with round black-bordered white spots on ocelli. The shoulder of wing is crimson whereas rest of the wing dark brown mottled with buff, the tail is black. Females are rufous with barred or blotched with black and buff. Pale shaft stripes are present on the crown. Shoulder of wing is tinged with crimson. The chin and throat are whitish, breast and abdomen like back but paler, mottled with large ill-defined whitish shaft spots. Tail is rufous brown irregularly barred with black and buff. Young and immature male are like females but less richly colored (Ali and Ripley 1987).

\section{Status, distribution and habitat}

It is resident in moist oak and rhododendron forest with dense undergrowth and bamboo clumps, mixed forest, scrub and densely vegetated ravines, usually between 2,200 m and 
4,250 $\mathrm{m}$ in the breeding season, sometimes moving down to 1,800 $\mathrm{m}$ in winter (Inskipp and Inskipp 1991).

\section{Ecology}

The species prefers oak and rhododendron forests and the bird exclusively dependents on forests. During the breeding time, it gives a loud, mammal sounding call especially at dawn (Ali and Ripley 1987). Places like Pipar and Santel have good populations of Satyr Tragopan. Long term monitoring studies at Pipar have shown that the population there is more or less stable (Poudyal and Singh 2005, Poudyal 2008). Elsewhere in the country, the bird has declined (Baral and Inskipp 2004).

\section{Threats}

Major threats include excessive hunting as well as habitat clearance and degradation due to timber harvesting, fuel wood and fodder collection and livestock grazing (Baral and Inskipp 2004).

\section{Conservation}

Previously it occurred from west to east Nepal throughout the midhills in suitable broadleaved forests. Hunting and loss of habitat have extirpated its population in many places including decline of population in protected areas eg. Langtang National Park (pers. obs.).

CITES has listed the species for Nepal in Appendix III (www.cites.org) and BirdLife has listed the species as Near-threatened (BirdLife International 2009).

\section{Danphe (Lophophorus impejanus)}

World distribution: Afghanistan, Pakistan, Nepal, India, Bhutan, Tibet and Myanmar World population: Not estimated

Nepal population: 10,000-20,000 individuals, Trend: Declining nationally

\section{IUCN/BirdLife International: Least Concern}

CITES: Appendix I.

(National bird of Nepal.)

\section{Field characters}

Length: $70 \mathrm{~cm}$, Weight: 1.8-2.4 kg (Ali and Ripley 1987). Adult males possess a long crest, and are feathered with multicoloured plumage throughout their body, while the females, like in other pheasants, are dull in colour with the upper parts covered with dark brownish-black feathers. Notable features in males are a long crest that is metallic green, changeable reddish 
copper on the back and sides of the neck and, a prominent white back and rump while in flight (Grimmett et al. 1998). Tail feathers of males are uniformly rufous being darker towards the tips, where as the lower tail coverts of females are white, barred with black and rufous. Females have a prominent white patch in the fore neck and a white strip on the tail. First year males and immatures resemble females, but first year males are larger and the immatures are less distinctly marked (Ali and Ripley 1987).

\section{Status, distribution and habitat}

Danphe secures a distinct position among pheasants due to its prominent build, brilliant plumage and strong association with local folklore. It occupies upper temperate oak-conifer forests interspersed with open grassy slopes, cliffs and alpine meadows. It is a fairly common resident subject to altitudinal movements found throughout Nepal in suitable habitat (Inskipp and Inskipp 1991).

\section{Ecology}

The bird mainly summers from 3,300m to 4,570m, and winters down to 2,500m (Inskipp and Inskipp 1991). It exhibits clear and fluctuating altitudinal migration reaching as low as $2,500 \mathrm{~m}$ in winter. It, however, shows tolerance to snow and has been observed to dig through snow for roots, tubers and other plant parts, and invertebrates. Seen in pairs during the breeding season (April to August), they form large coveys and involve in communal roosting during the winter. They are known to have elaborate courtship dancing behaviour (Ali and Ripley 1987). The population of this species in most of its range is threatened due to poaching and other anthropogenic factors. The male has been under heavy hunting pressure for its crest feather used for ornament hats in various parts of Nepal (Tika Giri pers. comm. 2000).

The scientific name commemorates Lady Mary Impey, the wife of British chief justice of Bengal, Sir Elijah Impey.

\section{Threats}

The main threats to the bird are hunting which is done for meat and to obtain its crest feathers. The bird is hunted mainly by shepherds and poachers even inside the park as the monitoring mechanism to curb these illegal actions are weak within our administration.

\section{Conservation}

The bird is wide ranging compared to other pheasants listed in Act. It is found west from Afghanistan east to China and parts of Myanmar (Ali and Ripley 1987). As it is found in high altitude during breeding period where human population is low -the species seems to have benefited compared to other galliforms. 


\section{Cheer Pheasant (Catreus wallichii)}

World Distribution: Pakistan, India, and Nepal.

World Population: 2,500-9,999

Nepal Population: 1,000-3,000

IUCN/BirdLife International: Vulnerable

CITES: Appendix I.

\section{Field characters}

Length: $61-118 \mathrm{~cm}$, Weight: $1.4-1.7 \mathrm{~kg}$ (Ali and Ripley 1987). It is a grey, brown and buff bar-tailed pheasant with long crest and red facial skin. Male has largely plain pale-greyish upper neck and clear, dark barring on upperparts. Female is smaller, somewhat duller and more heavily marked (Ali and Ripley 1987, Grimmett et al. 1998).

\section{Status, distribution and habitat}

It has always been reported as uncommon with a patchy distribution owing to its specialized habitat requirements which often brings it into close proximity to human populations. Many subpopulations are thought to number fewer than 10 individuals, living in small pockets of suitable habitat (BirdLife International 2009). It is a breeding resident from West Nepal East to Kali Gandaki Valley and appears to be localised, in midwest part especially the Dhorpatan Hunting Reserve and its adjoining areas (Acharya 2004, 2006). It is reported between 1,800m and 3050m, with little altitudinal movement (Inskipp and Inskipp 1991).

\section{Ecology}

Where this bird is present these sites are characterised by a combination of low shrubs subject to regular browsing and cutting, with tall dense grass in spring. Its preference for early successional habitats, often created by traditional grass cutting and burning regimes, has led to an association with human settlements (BirdLife International 2009).

\section{Threats}

It is hunted for food and eggs. The patchy nature of its specialised habitat may render the smallest isolated populations vulnerable to extinctions, and higher levels of disturbance, grazing and the felling of wooded ravines now pose a substantial threat (BirdLife International 2009). Conversion of grassland to permanent arable terraces is reducing available habitat, as are schemes to plant mid-altitude grasslands with forest (Baral and Inskipp 2004, Acharya 2005). 


\section{Conservation}

It occurs in at least three protected areas in Nepal, Dhorpatan Hunting Reserve, Rara National Park and Annapurna Conservation Area (Anon 2007, Acharya 2005).

There is a need to continue monitoring populations at as many key sites as possible. Results of scientific studies should be used to develop a species management plan to cover habitat prescriptions, public awareness and the enforcement of hunting bans. Further studies on burning and grazing regimes at known sites are needed to monitor their impact. Use it as a flagship species in producing and promoting habitat management recommendations based on these studies. Assess the effects of villagers upon the species and its habitat (Anon 2007).

\section{Great Hornbill (Buceros bicornis)}

World distribution: China, India, Nepal, Bangladesh, Bhutan, Myanmar, Thailand, Cambodia, Laos, Vietnam, Malaysia and Indonesia

World population: Not estimated

Nepal population: $<500$, Trend: Declining

IUCN/BirdLife International: Near-threatened

CITES: Appendix I.

\section{Field characters}

The Great Hornbill is a large bird, nearly four feet tall with a five foot wingspan, tail feathers reaching 3 feet long and a weight of three $\mathrm{kg}$. The most prominent feature of the hornbill is the bright yellow and black casque on top of its massive bill. Females are smaller than males and have blue instead of red eyes. The male spreads the preen gland secretion which is yellow onto the primaries and bill to give them the bright yellow colour (Ali and Ripley 1987, Grimmett et al. 1998). This is the largest forest hornbill of the world (del Hoyo et al. 2001).

\section{Status, distribution and habitat}

It is a local resident in thick forest of the Terai and duns, subject to seasonal movements. It frequents evergreen and mixed deciduous forests, ranging out into open deciduous areas to visit fruit trees (Ali and Ripley 1987). The abundance of this species tends to be correlated with the density of large trees, and it is therefore most common in unlogged forest. It is particularly susceptible to hunting pressure as it is large and visits predictable feeding sites (such as fruiting trees) (Fleming et al. 1984, del Hoyo et al. 2001).

\section{Ecology}

Female hornbills build nests in hollows of large tree trunks and the opening is sealed with feces, wood bark, and dirt. She remains imprisoned in her nest until the chicks are semi- 
developed relying on the male to bring her food. During this period the female undergoes a complete moult. She is fed by her mate through a slit in the seal. The clutch consists of one or two eggs she incubates for 38-40 days. The Great Hornbills form monogamous pair bonds and live out their lives in groups of 2-40 individuals. Group courtship displays involving up to 20 birds have been observed. Recently Basu Bidari of Bird Education Society has reported more than 50 Great Hornbills in one flock at Chitwan (pers. comm.). This is the largest number recorded in a flock.

In the wild, the Great Hornbill's diet consists mainly of fruit. It will also eat small mammals, birds, lizards, snakes and insects.

\section{Threats}

Loss of mature trees with cavities, scarcity of fruiting trees and other food items, hunting and disturbance are the major threats to the bird (Baral and Inskipp 2004).

\section{Conservation}

Now the main population of the hornbills is found in Greater Chitwan (Chitwan National Park and Parsa Wildlife Reserve) and Bardia National Park (Baral and Inskipp 2004). Reports from Sukla Phanta Wildlife Reserve and occasional reports from the southeastern lowland indicate the last remaining individuals in the area. If conditions do not improve population will be extirpated in few years' time. This is true for populations that remain outside protected areas as well as for the population that remain as fragmented populations eg Suklaphanta Wildlife Reserve.

Education and awareness activities, participatory habitat protection in community managed forests and protected areas are needed.

\section{Bengal Florican (Houbaropsis bengalensis)}

World distribution: It has two disjunctive populations, one in the Indian subcontinent (India, Nepal, Bangladesh), and other in the South-East Asia (Cambodia and Vietnam).

World population: 250 to 999 individuals

Nepal population: $<50$ individuals

IUCN/BirdLife International: Critically Endangered

CITES: Appendix I.

\section{Field characters}

Length: $66-68 \mathrm{~cm}$, Weight: $1.8-2.25 \mathrm{~kg}$. The male is mostly black with largely white wings during the breeding period. In flight, wings are entirely white except for black tips. Female and immature are buff-brown to sandy-rufous, and have buffish-white wing-coverts with fine, dark barring. Similar Lesser Florican (Sypheotides indica) is smaller and longer-necked. 
Male has white collar across upper mantle and white wing-coverts. Female has more prominent pale wing-coverts.

\section{Status, distribution, habitat and ecology}

It inhabits lowland dry, or seasonally inundated, natural and semi-natural grasslands, often interspersed with scattered scrub or patchy open forest. Local and uncommon; mainly a summer visitor and small population may be resident. Its migratory behaviour is little known (BirdLife International 2009).

\section{Threats}

The key threat is extensive loss and modification of grasslands through drainage, conversion to agriculture, overgrazing, inappropriate cutting and burning regimes and heavy flooding. Other threats include human disturbance and trampling of nests by livestock (Baral and Inskipp 2004, BirdLife International 2009).

\section{Conservation}

Several important populations occur within protected areas, the most important being Chitwan National Park, Bardia National Park and Sukla Phanta Wildlife Reserve (Inskipp and Inskipp 1991).

Major conservation recommendations are: continue surveys for populations, monitor known populations inside and outside protected areas. Extend, upgrade and link protected areas in India and Nepal, establish new ones and restoration of habitat.

\section{Lesser Florican (Sypheotides indica)}

World distribution: India and Nepal

World population: 2,206

Nepal population $<10$ individuals

IUCN/BirdLife International: Endangered

CITES: Appendix II.

\section{Field characters}

Length: $46-51 \mathrm{~cm}$, Weight: $0.51-0.74 \mathrm{~kg}$ (Ali and Ripley 1987). It is a small, slender bustard with longish bill and legs. Male has spatulate-tipped head plumes, black head, neck and under parts. White collar across upper mantle, white wing-coverts. Female and immature are sandy or cinamon-buff. 


\section{Status, distribution and habitat}

There have been several records of the birds as late as 1980s of this bird mainly from Chitwan (Inskipp and Inskipp 1983). There are only few reliable records of the birds, most recent one from Koshi Tappu (Cox 1998). Unlike its bigger cousin this bird in Nepal seems to migrate with patterns associated with monsoon. It is an irregular and late summer visitor to Nepal. Its main preference is short grassland but can be also found in cultivated lands.

\section{Ecology}

It is mainly a scarce summer visitor. Frequents grasslands with scattered bushes and cultivation. It should be mainly looked for in the southwestern lowland Nepal. Non-breeding season movements are poorly understood.

\section{Threats}

Severe hunting pressure, particularly of males for sport and also food, precipitated its decline. More recently, declines have been caused by rapid reductions in the area of grassland owing to conversion for agriculture and overgrazing. Over the last two decades, unreliable monsoon rains have caused significant population fluctuations.

\section{Conservation}

The bird is included in the protected bird list of Nepal. Conservation recommendations will be to survey and monitor population size and trends. Identify main grassland habitats or cultivation areas for the species. Promote local participation in grassland restoration and continue to employ local people as guardians of floricans and their habitats.

\section{Sarus Crane (Grus antigone)}

World distribution: Grus antigone India, Nepal, Myanmar, Vietnam, Cambodia, China, Laos and Australia

World population: $19,300-21,800$

Nepal population: $150-500$ in Nepal

BirdLife International/IUCN: Vulnerable

CITES: Appendix II.

\section{Field characters}

Height: $176 \mathrm{~cm}$, Weight: $6.35 \mathrm{~kg}$, Wingspan: $240 \mathrm{~cm}$ (Ali and Ripley 1987). It's a large, elegant, light grey crane. The head, throat, and the upper neck are covered with rough orange/red skin. Legs and toes have a shade of red. Males and females are virtually indistinguishable but within pairs, females are usually smaller than males (Grimmett et al. 1998). The heads of juveniles are covered with cinnamon brown feathers, and the greyish 
ear patch is not yet obvious. Body plumage changes from cinnamon brown to grey as the bird matures. This is also the tallest of all the flying birds of the world (Johnsgard 1983).

\section{Status, distribution and habitat}

Once, the cranes were distributed along the entire belt of lowland Nepal from east to west. However with advent of time, their range was significantly reduced especially because of hunting and habitat loss (Meine and Archibald 1996). Sarus Cranes in Nepal have been mainly confined to west of Narayani River. Their strongholds are Rupandehi, Kapilvastu and Nawalparasi districts (Suwal 1999). At present this is the only protected bird species whose more than $90 \%$ country's population is outside protected area.

\section{Ecology}

Sarus Cranes are mostly non-migratory in Nepal although pre-breeding roosts have been noted in April and May. They have adapted to the dense human population, and interact closely with people in areas where traditions of tolerance prevail (Suwal 1999). Sarus Cranes utilize a wide variety of landscapes, depending on food availability, cropping patterns, and other seasonal factors. Their optimal habitat includes a combination of cultivated fields especially rice paddies, small seasonal marshes and floodplains. Often they focus their foraging on underground tubers of native wetland vegetation such as Eleocharis spp. Breeding pairs place their nests in a wide variety of natural wetlands, along canals and irrigation ditches, beside village ponds, and in rice paddies. Compared to other crane species, Sarus Cranes will utilize open forests where wetlands occur as well as in open grasslands more so than other crane species. Where possible, the nests are located in shallow water where short emergent vegetation is dominant. For nesting they use rice paddies and wetlands nearby human settlements (Meine and Archibald 1996).

Sarus breed primarily during the rains. Nests of all Sarus Cranes consist of wetland vegetation. In Lumbini, nests located in flooded rice paddies are constructed entirely of rice stalks (Suwal 1999). Females usually lay two eggs and incubation (by both sexes) lasts 31-34 days. The male takes the primary role in defending the nest against possible danger. Chicks fledge (first flight) at 50-65 days.

Sarus Cranes are omnivorous and feed on aquatic plants such as tubers of sedges (such as Eleocharis spp.), invertebrates, grains, small vertebrates, and insects.

\section{Threats}

The main threats are a combination of loss and degradation of wetlands, as a result of drainage and conversion to agriculture, wetland pollution from pesticides, fertilizers and industrial effluent, siltation owing to catchment deforestation and river basin alterations, and 
the hunting of adults and collection of eggs and chicks for trade, food, medicinal purposes and, in some areas, collision with power lines, human disturbance and to control populations where it is considered a crop pest (Meine and Archibald 1996).

\section{Conservation}

Government has supported various education and awareness initiative and has produced postal stamps. Lumbini Crane Conservation Centre, NGO dedicated to education, awareness and conservation of Sarus has done significant work in the country to save Sarus with a focus in Lumbini (Suwal 1999). Himalayan Nature and Bird Conservation Nepal have done some education and awareness programmes in Lumbini farmlands which is an Important Bird Area (Baral and Inskipp 2005). Lumbini Buddha Garden, an eco-lodge by the bank of holy Telar River has invested resources to protect nesting sites, for education and awareness on Sarus in Lumbini (Sharad Singh pers comm. 2008).

Future conservation activities should include a thorough survey in lowland Nepal, regulate access to important nesting-grounds during the breeding season and important permanent wetlands in the dry season. Work with local farmers to minimize pesticide use and with industrialists to stop industrial effluent disposal around feeding areas eg Bhairahawa. Target further conservation awareness campaigns at communities in and around important sites eg Rupandehi, Kapilvastu and Nawalparasi districts south of East West Highway (Suwal 1999).

\section{White Stork (Ciconia ciconia)}

World distribution: Europe, Africa and Asia

World Population: 500,000 and 520,000 individuals (estimate)

Nepal Population: $<1$ adult, last report of an individual in 1996 from Koshi Tappu

IUCN/BirdLife International: Least Concern

CITES: Appendix Not listed

\section{Field characters}

Height: $100-125 \mathrm{~cm}, 155-200 \mathrm{~cm}$ wingspan and Weight: $2.3-4.5 \mathrm{~kg}$. It is completely white except for the black wing flight feathers, and its red bill and legs, which are black on juveniles. It walks slowly and steadily on the ground. Like all storks, it flies with its neck outstretched (Ali and Ripley 1987, Grimmett et al. 1998).

\section{Status, distribution and habitat}

In Nepal, it has been known from only a handful of records (Inskipp and Inskipp 1991). The stork passes the country only on migration and its migratory movements/routes through Nepal are not well known. 


\section{Ecology}

White storks breed in open farmland areas with access to marshy wetlands, building a stick nest in trees, on buildings, or special platforms. Like most of its relatives, it feeds mainly on frogs and large insects, but also young birds, lizards and rodents. The white stork is almost silent except for the noisy mutual bill-clattering when adults meet at the nest. White Storks rely on movement between thermals of hot air for long distance flight, taking great advantage of them during annual migrations (Snow and Perrins 1998).

\section{Threats}

Threats to the species include the drainage of wetlands and other agricultural intensification, collisions with overhead power lines, use of persistent pesticides, and hunting on passage and the wintering grounds (Snow and Perrins 1998).

\section{Conservation}

None specific to this country other than listing it as a protected bird. Education and awareness programmes combined with securing large shallow wetlands and mudflats in central and western lowlands should be conservation priority for this bird.

\section{Black Stork (Ciconia nigra)}

World distribution: Europe, Africa and Asia

World population: $32,000-44,000$

Nepal population: $500-1,500$ individuals

IUCN/BirdLife International: Least Concern

CITES: Appendix II.

\section{Field characters}

Height: $106 \mathrm{~cm}$, Weight: $3.17 \mathrm{~kg}$. It is a widespread, but rare, species that breeds in the warmer parts of Europe, predominantly in central and eastern regions and in north Asia. It is all black except for the white belly and axillaries, and its red bill and legs. It walks slowly and steadily on the ground. Like all storks, it flies with its neck outstretched (Ali and Ripley 1987, Snow and Perrins 1998).

\section{Status, distribution and habitat}

It is fairly common winter visitor lowland Nepal. It prefers river banks and large water bodies. 


\section{Ecology}

It breeds in large marshy wetlands with interspersed coniferous or broadleaved woodlands, but also inhabits hills and mountains with sufficient network of creeks. It builds a stick nest high in trees. This is a shy and wary species, unlike the closely related White Stork (Snow and Perrins 1998).

The Black Stork feeds mainly on fish and also amphibians and insects. It has a rasping call, but rarely indulges in mutual bill-clattering when adults meet at the nest (Snow and Perrins 1998). The Black Stork is a strong migrant, wintering in tropical Africa and Asia.

\section{Threats}

Hunting (during migration and on the wintering ground) is the major threat for this species. This is done for meat as well as for medicinal purpose. Some also hunt for fun and pleasure. Another threat to the bird in this country is loss of habitat and its alteration (Baral and Inskipp 2004).

\section{Conservation}

Most of Nepal's Black Stork winter mainly in protected areas where they are considered safe. However some that forage outside bear risk of being killed. As it is widely distributed stork species and elsewhere in its range birds' population remains stable, is considered Least Concern.

\section{Reference}

Acharya, (Sharma), R. 2004. Survey of the Cheer Pheasant (Catreus wallichii) (Hardwicke, 1827) in lower Kali Gandaki valley, Mustang, Nepal. Report to King Mahendra Trust for Nature Conservation, Annapurna Conservation Area Project, Nepal; World Pheasant Association, UK; School of Environmental Management and Sustainable Development, Nepal. Unpublished.

Acharya, (Sharma), R. 2005. Cheer conservation. Nepal Trust for Nature Conservation and Friends of Nature Nepal, Kathmandu. (In Nepali).

Acharya, (Sharma), R. 2006. Does Cheer Pheasant Catreus wallichii exist east of Kaligandaki Valley, Nepal? Danphe 15(1): 7-8.

Ali, S. and Ripley, S. D. 1987. Compact handbook of the Birds of India and Pakistan. New Delhi: Bombay Natural History Society.

Anonymous 2007. Cheer Advocacy Document. World Pheasant Association, Bird Conservation Nepal and National Trust for Nature Conservation, Kathmandu.

Baral, H. S. 2005. Status and conservation of Nepal's Galliformes: an update 1-4. In R. Fuller and S. Browne, eds. Galliformes 2004. Proceedings of the $3^{\text {rd }}$ International 
Galliformes Symposium, Dehra Dun and Corbett National Park, India, $5^{\text {th }}-10^{\text {th }}$ April 2004. Fordingbridge, UK: The World Pheasant Association.

Baral, H. S. and Inskipp, C. 2004. The state of Nepal's birds 2004. Kathmandu: Department of National Parks and Wildlife Conservation, Bird Conservation Nepal and IUCN Nepal.

Baral, H. S. and Inskipp, C. 2005. Important Bird Areas in Nepal: key sites for conservation. Kathmandu, Nepal and Cambridge, UK: Bird Conservation Nepal and BirdLife International.

Basnet, Y. R. (2002) Raja Rani Pokhari: an important bird habitat Danphe 11(4): 1-2.

Basnet, Y. R. (2003a) Bird diversity of Morang Siwalik Hills. Danphe 12(1/2): 10-11.

BirdLife International (2009) Species factsheet: Houbaropsis bengalensis. Downloaded from http://www.birdlife.org on 11/7/2009.

BirdLife International (2009) Species factsheet: Buceros bucornis. Downloaded from http://www.birdlife.org on 11/7/2009.

BirdLife International (2009) Species factsheet: Tragopan satyra. Downloaded from http:/ /www.birdlife.org on 11/7/2009.

BirdLife International (2009) Species factsheet: Sypheotides indica. Downloaded from http://www.birdlife.org on 11/7/2009.

BirdLife International (2009) Species factsheet: Catreus wallichi. Downloaded from http:// www.birdlife.org on 11/7/2009.

Cox, J. Jr 1998. Breeding birds of Dharan-Koshi area Ibisbill 1: 108-117.

Del Hoyo, J., Elliott, A. and Sargatal, J. (Eds) 2001. Handbook of the birds of the world. Mousebirds to Hornbills. Volume 6. Lynx Edicions, Barcelona.

Fleming, R. L. Sr, Fleming, R. L. Jr and Bangdel, L. S. 1984. Birds of Nepal. $3^{\text {rd }}$ edition. Kathmandu:Avalok.

Grimmett, R., Inskipp, C. and Inskipp, T. 1998. Birds of the Indian Subcontinent. London, UK. Christopher Helm.

Grimmett, R., Inskipp, C. and Inskipp, T. 2000. Birds of Nepal. London, UK: Christopher Helm.

Inskipp, C. and Inskipp, T. 1991. A guide to the birds of Nepal. $2^{\text {nd }}$ edition. London, UK: ChristopherHelm.

Inskipp, C. and Inskipp, T. P. 1983. Report on a survey of Bengal Floricans Houbaropsis bengalensis in Nepal and India, 1982. Study Report No. 2. Cambridge, U.K.: International Council for Bird Preservation.

Johnsgard P. A. 1983. Cranes of the world. Bloomington: Indiana University Press. 
Meine C. D. and Archibald G. W. 1996. The cranes: status survey and conservation action plan. Gland, Switzerland: IUCN.

Poudyal, L. P. 2008. "Distribution and habitat use of pheasants in the headwater forests of Seti Khola, Annapurna Conservation Area, Nepal Progress" report to Institute of Forestry, Pokhara for MSc in Natural Resource Management and Rural Development. July 2008. Unpublished.

Poudyal, L. P. and Singh, P. 2005. "A survey of Galliformes population in Pipar Reserve, Annapurna Conservation Area, central Nepal, 2005" report to World Pheasant Association. Unpublished.

Poudyal, L. P., Singh, P. B. and Maharajan, S. 2008. The decline of Bengal Florican Hourbaropsis bengalensis in Nepal. Danphe 17(1): 4-6.

Snow, D. W. and Perrins, C. M. 1998. The Birds of the Western Palearctic. Concise Edition. Oxford University Press, Oxford.

Suwal, R. N. 1999. Study on the habitat preference, movements, nesting and population dynamics of Sarus Crane Grus antigone of Lumbini. MSc Thesis. Tribhuvan University, Kathmandu. Unpublished. 